\title{
PEMBUATAN ALAT UKUR KELAJUAN ANGIN MENGGUNAKAN SENSOR OPTOCOUPLER DENGAN DISPLAY PC
}

\author{
Nurfitriza Yanti, Yulkifli, Zulhendri Kamus \\ Jurusan Fisika Universitas Negeri Padang. \\ Jl Prof. Dr. Hamka Air Tawar Barat Padang. \\ Email:nurfitrizayanti@gmail.com
}

\begin{abstract}
The wind is one of the important parameters in meteorology to determine weather and climate. It can be determined by using two quantity measured, such us speed and direction of wind. Based on the result of measuring will obtain important information that can be used for disaster prevention. For measuring of wind speed, this reserch design a measurement using optocoupler sensor to determine wind speed with change of sensor resistance. The sensor is conected to an electronic circuit and a microcontroller Arduino Uno Rev3 and it is programmed to get the desired results. Based on data analysis, there are two result of research namely performance and design specifications. The instrument consists of two parts; the electronic circuits and mechanical parts making up the system of measuring instruments of wind speed. Based on the results conducted, the accuracy of this measuring instrument is $91.39 \%$ with $3.22 \%$ error percentage and the accuracy of the instrument was $98.9 \%$ with $1: 11 \%$ relative error percentage.
\end{abstract}

Key words: sensor optocoupler, microcontroler arduino

\section{PENDAHULUAN}

Pengukurandidefinisikan sebagai suatu proses membandingkan suatu besaran dengan besaran lain yang sejenis yang dipakai sebagai satuan. Besaran merupakan sesuatu yang diukur dan dapat dinyatakan dengan angka atau nilai yang memiliki satuan. Pengukuran suatu besaran biasanya dilakukan menggunakan alat ukur.

Angin merupakan salah satu unsur penting dalam meteorologi menentukan kondisi cuaca dan iklim pada suatu tempat. Angin dapat ditentukan dengan menggunakan dua parameter atau besaran yang diukur, yang pertama yaitu kelajuan atau kecepatan angin dan yang kedua yaitu arah angin. Melalui pengukuran kelajuan dan arah angin akan di dapatkan informasi penting yang dapat digunakan untuk keperluan seperti pencegahan bencana yang akan ditimbulkan oleh angin itu sendiri. Untuk mendapatkan data pengukuran kelajuan yang akurat diperlukan suatu alat ukur. Pengukuran kelajuan angin dapat dilakukan dengan berbagai metode dengan kelebihan dan kekurangan masing-masing metode tersebut.
Alat ukur kelajuan dan arah angin yang umum digunakan pada stasiun pengamat cuaca adalah Anemometer jenis Cup Counter yang menerapkan metode mekanik dalam pengukurannya. Anemometer jenis Cup Counter adalah alat yang digunakan untuk mengukur laju angin dengan tiga buah cup sebagai sensor yang dihubungkan oleh lengan ke couter. Prinsip kerja alat ini yaitu apabila angin bertiup maka rotor berputar pada arah tetap disebabkan karena seluruh cup menghadap ke satu arah melingkar. Perputaran sumbu sistem Cup dihubungkan secara mekanik dengan generator sinyal sebagai pencatatan sinyal.

Komponen yang digunakan untuk Anemometer jenis Cup Counter tidak terdapat di Indonesia. Apabila terjadi kerusakan pada alat maka tidak dapat diperbaiki secara langsung dan komponen alat ini berharga cukup mahal. Stasiun pengamatan cuaca di Indonesia memerlukan biaya yang cukup untuk mendapatkan Anemometer jenis Cup Counter, hal ini disebabkan karena alat ukur ini harus diimpor dari luar negeri. Selain itu Anemometer yang terdapat di Stasiun pengamatan cuaca 
tidak terkoneksi ke komputer, sehingga data kelajuan dan arah angin ini masih di ambil secara manual oleh observer tiap 1 jam untuk dicatat ke dalam buku synop kemudian baru dikirim ke pihak BMKG pusat.

Pada penelitian ini penulis membuat perancangan mekanik alat dengan memanfaatkan sensor optocoupler sebagai penghitung kelajuan angin yang akan mendeteksi perubahan tahanan berdasarkan perubahan angin. Sensor dihubungkan dengan rangkaian elektronika dan mikrokontroler Arduino Uno Rev3 dan memprogramnya untuk mendapatkan hasil yang diinginkan. Kemudian untuk keluaran atau output dari pengukuran ditampilkan ke Personal Computer (PC). Sehingga dengan adanya penelitian ini diharapkan dapat menghasilkan suatu alat ukur kelajuan angin yang murah, handal dan memudahkan observer dalam melakukan pengukuran kelajuan angin.

Berdasarkan uraian yang telah dipaparkan maka penelitian ini akan membuat alternatif rancangan sebuah alat yang menggunakan instrumentasi elektronika untuk melakukan pengukuran kelajuan angin dengan judul "Pembuatan Alat Ukur Kelajuan Angin Menggunakan Sensor Optocoupler Dengan Display PC"

Massa udara yang bergerak disebut angin. Angin dapat bergerak secara horizontal maupun vertikal dengan kelajuan yang bervariasi dan berfluktasi secara dinamis. Menurut Safrianti (2010:30), “Angin adalah udara yang bergerak dari tekanan tinggi ke tekanan rendah atau dari suhu udara yang bertekanan rendah ke suhu udara yang lebih tinggi." Jadi dapat disimpulkan faktor pendorong bergeraknya massa udara adalah perbedaan tekanan udara antara suatu tempat dengan tempat lain.

Angin dapat ditentukan dengan dua parameter yaitu arah angin dan kecepatan atau kelajuan angin. Satuan yang digunakan untuk besaran arah angin biasanya adalah derajat. 1 derajat untuk angin arah Utara, 90 derajat untuk angin arah dari Timur, 180 derajat untuk angin arah dari Selatan dan 270 derajat untuk angin arah dari Barat.

Dasar untuk menghitung kelajuan angin adalah menggunakan perbandingan antara jarak tempuh dengan waktu yang diperlukan. Melalui persamaan berikut:

$$
V=\frac{s}{t}
$$

Dimana, $V$ merupakan kelajuan atau kecepatan, $S$ jarak tempuh dan $t$ yaitu waktu.

Pada dasarnya kelajuan dan kecepatan mengandung arti yang sama karena memiliki satuan yang sama yaitu $\mathrm{m} / \mathrm{s}$, hanya saja kecepatan merupakan besaran vektor yang mempunyai arah sedangkan kelajuan merupakan besaran skalar yang tidak bergantung pada arahnya. Kelajuan angin pada dasarnya juga ditentukan oleh perbedaan tekanan udara antara tempat asal dan tujuan angin (sebagai faktor pendorong) dan resistansi medan yang dilaluinya.

Menurut hukum Buys Balot, udara bergerak dari dari daerah yang bertekanan tinggi (maksimum) ke daerah bertekanan rendah (minimum), di belahan bumi utara berbelok ke kanan, sedangkan di belahan bumi selatan berbelok ke kiri. Kelajuan angin dapat dinyatakan dalam $\mathrm{m} / \mathrm{s}, \mathrm{km} / \mathrm{jam}, \mathrm{mil} / \mathrm{jam}$ atau knots. Hubungan antara masing-masing satuan ini adalah $6.28 \mathrm{~m} / \mathrm{s}=22.08 \mathrm{~km} / \mathrm{jam}=2.25$ $\mathrm{mil} / \mathrm{jam}, 1 \mathrm{~m} / \mathrm{s}=3.6 \mathrm{~km} / \mathrm{jam}=2 \mathrm{knots}, 1$ $\mathrm{km} / \mathrm{jam} 10 / 36 \mathrm{~m} / \mathrm{s}=0.62 \mathrm{mil} / \mathrm{jam}, 1 \mathrm{mil} / \mathrm{jam}=$ $0.447 \mathrm{~m} / \mathrm{s}=1.6 \mathrm{~km} / \mathrm{jam}$ dan 1 knots $=0.5 \mathrm{~m} / \mathrm{s}$ $=1.8 \mathrm{~km} / \mathrm{jam}$.

Pembuatan alat ukur ini menggunakan sebuah sensor yaitu optocoupler. Optocoupler dapat didefinisikan sebagai piranti elektronika yang memanfaatkan sinar sebagai pemicu onoff Optocoupler atau isolator optik (optoisolator) merupakan rangkaian terpadu yang terdiri dari fototransistor dan LED (light emitting diode) kombinasi antara emitter dan detektor.

Di dalam sebuah penelitian yang berjudul "Alat Penunjuk Arah Angin dan Pengukur Kecepatan Angin Berbasis Mikrokontroler AT89C51" yang ditulis oleh Bonadin, dkk. (2005) mengungkapkan bahwa opto adalah optik dan coupler merupakan pemicu maka Optocoupler adalah komponen yang bekerja berdasarkan picu dari cahaya optik yang terdiri dari transmitter dan recevier.

Transmitter dibangun dari LED infra merah yang cahayanya tidak dapat dilihat secara kasat mata. LED infra merah memiliki ketahanan yang lebih baik terhadap sinyal tampak jika dibandingkan dengan LED biasa. 
Recevier dibangun dari sebuah fototransistor yaitu transistor yang peka terhadap tenaga cahaya. Spektrum infra merah yang merupakan sumber cahaya menghasilkan energi panas yang lebih besar dibandingkan dengan cahaya tampak.

Ditinjau dari segi penggunaannya, fisik Optocoupler dapat berbentuk bermacammacam. Bila hanya digunakan untuk mengisolasi level tegangan atau data pada sisi transmitter dan sisi receiver, maka Optocoupler ini biasanya dibuat dalam bentuk solid (tidak ada uang antara LED dan Photodiode). Sehingga sinyal listrik yang ada pada input dan output akan terisolasi. Dengan kata lain Optocoupler ini digunakan sebagai optoisolator jenis IC.

Sebagai piranti elektronika yang berfungsi sebagai pemisah antara rangkaian power dengan rangkaian kontrol. Komponen ini meupakan salah satu jenis komponen yang memanfaatkan sinar sebagai pemicu on/offnya.Dasar rangkaian dapat ditunjukkan seperti pada Gambar 1.

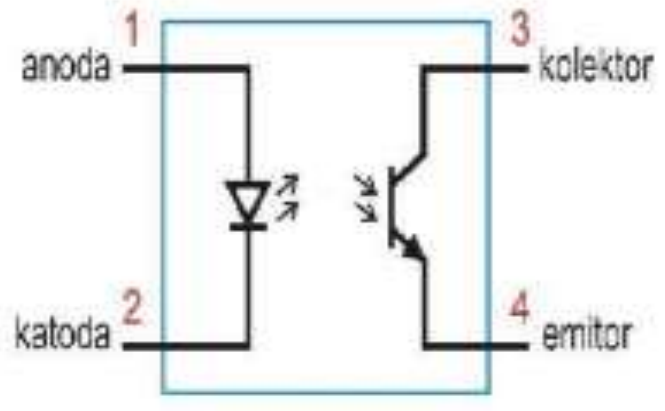

(a)

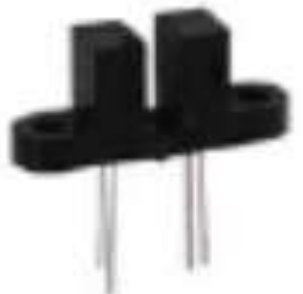

(b)

Gambar 1. Rangkaian dasar Optocoupler

Sebagai pemancar atau transmitter dibangun dari sebuah led infra merah untuk mendapatkan ketahanan yang lebih baik daripada menggunakan led biasa. Sensor ini bisa digunakan sebagai isolator dari rangkaian tegangan rendah kerangkaian tegangan tinggi dan sebagai pendeteksi adanya panghalang antara transmitter dan receiver dengan memberi ruang uji dibagian tengah antara led dengan photo transistor. Penggunaan ini dapat diterapkan untuk mendeteksi putaran motor atau mendetaksi lubang penanda disket pada disk drive komputer, namun Optocoupler untuk mendeteksi putaran.

Subito (2012:185), didalam penelitiannya "Alat Pengukur Pemakaiaan Energi Listrik Menggunakan Sensor Optocoupler dan Mikrokontroler AT89S52", menyimpulkan bahwa prinsip kerja dari optcoupler adalah jika antara transistor dan LED terhalang maka fototransistor tersebut akanoff sehingga keluaran dari kolektor akan berlogika high. Namun jika antara transistor dan LED tidak terhalang maka fototransistor tersebut akanon sehingga keluaran dari kolektor akan berlogika low.

Komponen-komponen penting lainnya yang membangun sistem alat ukur ini adalah Mikrokontroler Arduino suatu papan elektronik yang mengandung mikrokontroler Atmega 328 (sebuah keping yang secara fungsional bertindak seperti sebuah komputer). Peranti ini dapat dimanfaatkan untuk mewujudkan rangkaian kompleks. Pengendalian LED hingga pengontrolan robot dapat diimplementasikan dengan menggunakan papan yang berukuran relatif kecil, seperti yang terlihat pada Gambar 2. 


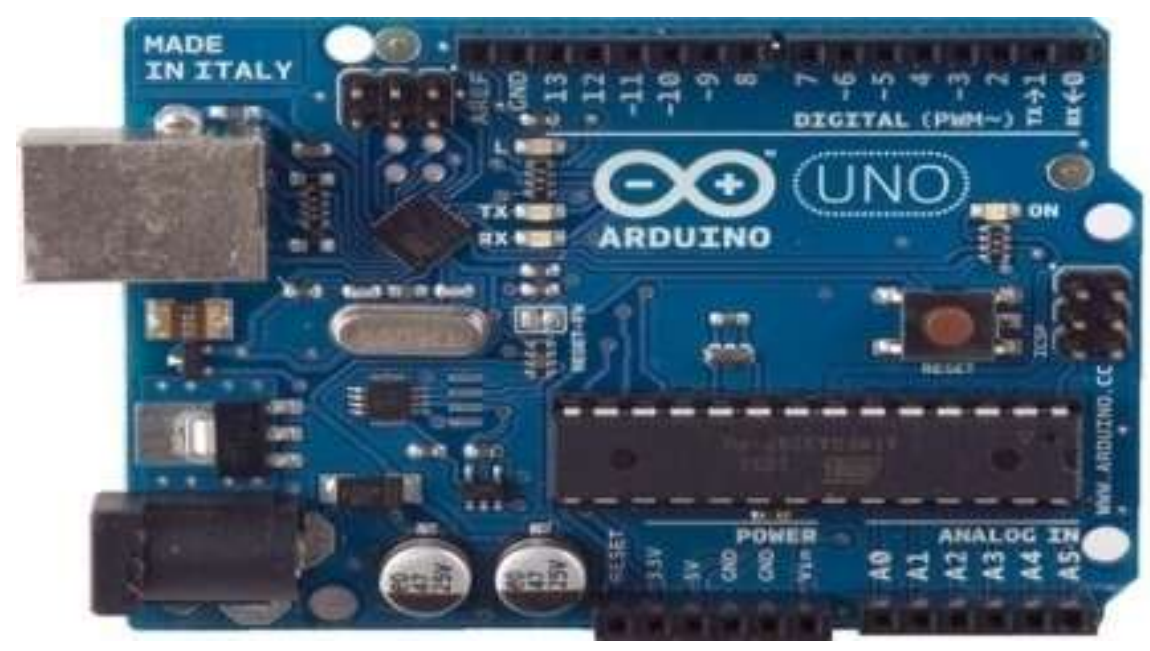

Gambar 2. Board Arduino Uno Rev3

Catu daya yang digunakan pada alat ini memiliki tegangan 9 volt. Catu daya merupakan suatu peralatan yang sangat penting karena hampir semua peralatan elektronika memerlukan tegangan DC untuk mengoperasikannya. Catu daya adalah suatu alat yang mengubah tegangan $\mathrm{AC}$ menjadi tegangan DC. Gambar catu daya dapat dilihat pada Gambar 3.

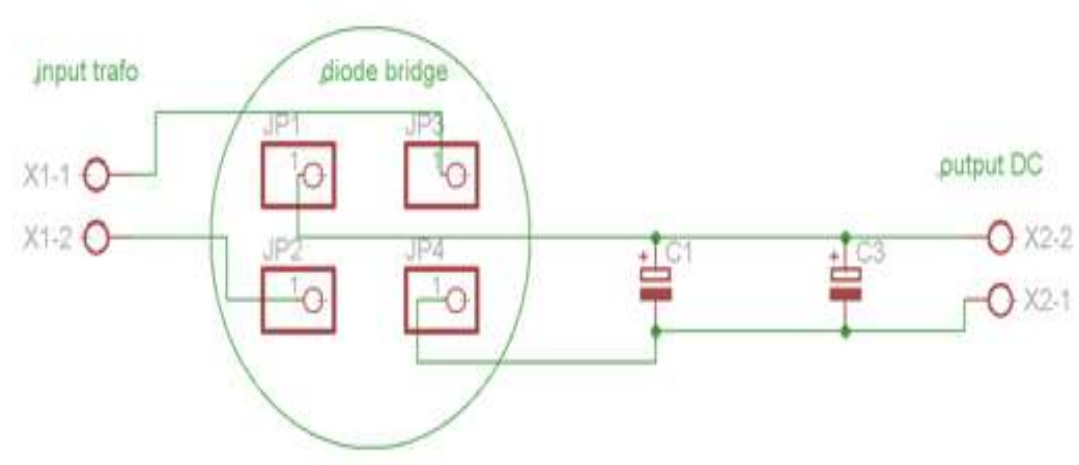

Gambar 3 Catu Daya

Tegangan teregulasi dapat diperoleh dengan memilih seri IC regulator yang sesuai, tegangan teregulasi berfungsi agar tegangan yang dibutuhkan sesuai dengan keinginan, untuk mengurangi ripple dari power supply yang kita buat maka dibagian keluaran dari power supply ditambahkan kapasitor, salah satu catu daya teregulasi

\section{METODE PENELITIAN}

Penelitian dilakukan di Laboratorium Elektronika dan Instrumentasi Jurusan Fisika FMIPA Universitas Negeri Padang.Pelaksanaan kegiatan dimulai bulan April 2015 sampai dengan bulan Agustus 2015 dengan beberapa tahap kegiatan. 


\section{Desain Perangkat Keras}

Desain perangkat keras dari alat ukur ada 2 yaitu desain rangkaian elektronika pembangun sistem dan desain mekanik alat ukur. Desain rangkaian elektronika darialat ukur membahas tentang alur rangakaian serta komponen-komponen apa saja yang diguanakan dalam pembuatan sistem. Desain rangkaian elektronika dari sistem biasanya digambarkan dalam bentuk blog diagram, blog diagram dari sistem pembangun alat ukur ini dapat dilihat pada Gambar 6.

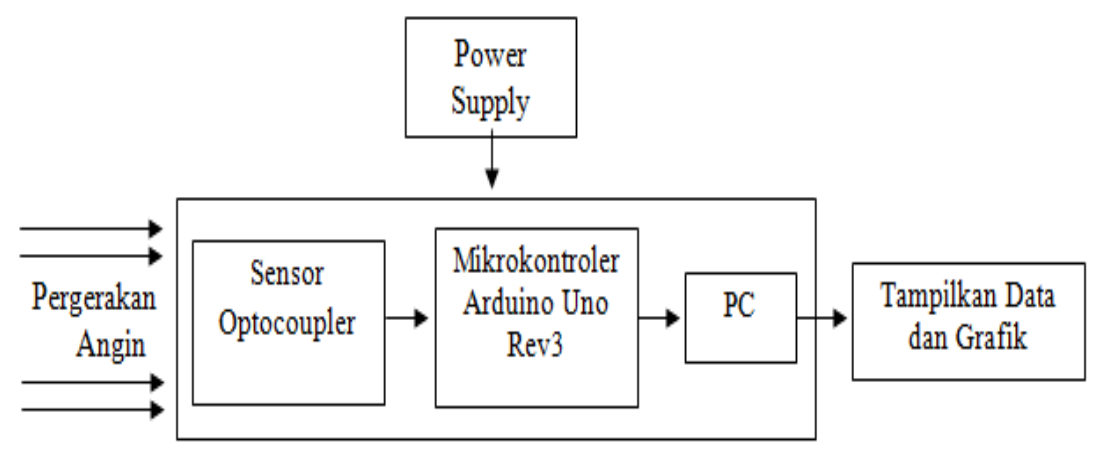

Gambar 4. Blog Diagram Sistem Alat Ukur

Pada blog diagram Gambar 4 dapat dijelaskan bahwa pada sistem alat ukur nilai kecepatan dan arah angin ini, power supply digunakan sebagai catu daya pada komponen alat ukur, sinyal input yang berasal dari sensor optocoupler. Pada saat angin melewati balingbaling mangkok dan yang dihubungkan dengan sensor optocoupler maka sensor akan menangkap sinyal dan mengkonversi sinyal keluaran dari optocoupler ke rangkaian mikrokontroler Arduino Uno Rev3 yang telah diprogram untuk segera diproses dan menampilkanny pada layar PC (Personal Computer).

Desain perangkat keras kedua yaitu desain mekanik dari alat ukur, desain mekanik di rancang berdasarkan posisi berdiri dari orang yang akan diukur. Desain mekanik dari alat ukur dapat dilihat pada Gambar 5.

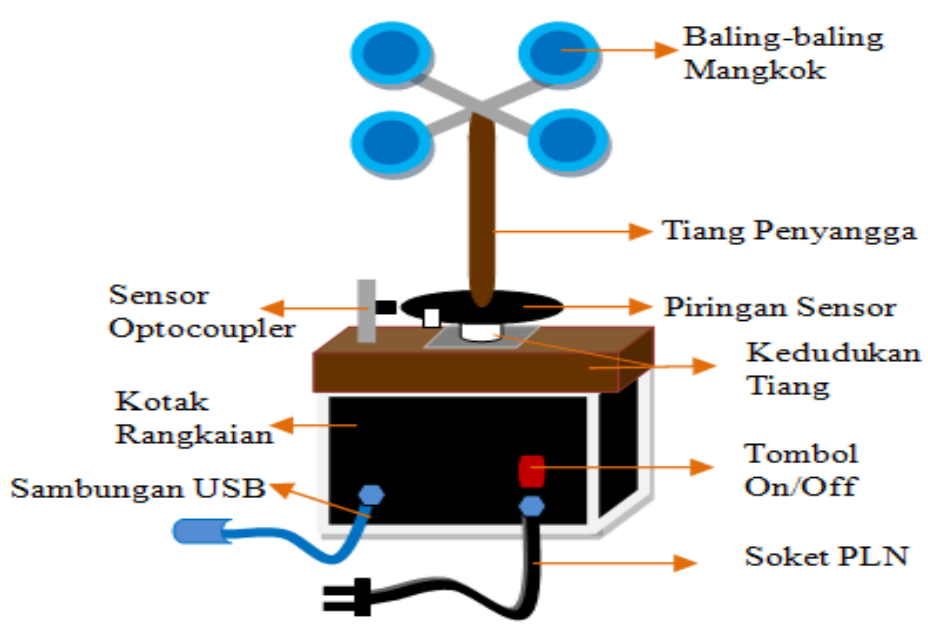

Gambar 5 Desain Mekanik Alat Ukur 
Pada Gambar 5 dapat dilihat desain alat secara keseluruhan yang sebenarnya terdiri dari dua bagian.Bagian pertama adalah bagian sistem mekanik alat ukur yang terdiri dari baling-baling mangkok dengan tiang penyangga beserta dudukannya yang terbuat dari kayu.Pada badan tiang penyangga dipasang sebuah piringan cakram yang didepannya juga dipasangkan rangkaian sensor optocoupler. Bagian kedua box atau kotak yang berfungsi untuk meletakkan rangkaian elektronika pembangun sistem, yang terdiri dari tombol power, soket PLN dan sambungan USB.

\section{Desain Perangkat Lunak}

Perangkat lunak ini berfungsi untuk memberikan instruksi dan menjalankan perangkat lunak berkaitan dengan kinerja perangkat keras. Perangkat lunak pada sistem mikrokontroler biasa juga disebut firmware mikrokontroler. Gambar 6 menunjukkkan diagram alir program alat ukur.

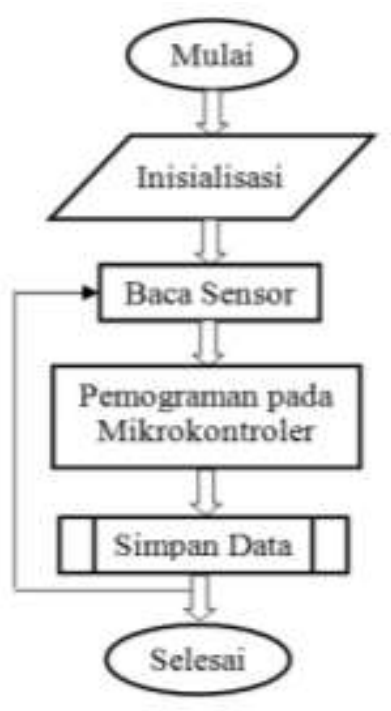

Gambar 6. Flowchart Alat Ukur

Gambar 6 merupakan diagram alir pemograman alat ukur kelajuan Angin Menggunakan Sensor Optocoupler dengan Display Personal Computer (PC). Proses yang pertama dalam pemograman adalah proses inisialisasi Mikrokontroler Arduino yang digunakan kemudian dilanjutkan dengan pembacaan sensor serta pengolahan hasil pembacaan sensor oleh Mikrokontroler Arduino dan hasil akan ditampilkan pada PC dengan tampilan nilai dan grafik melalui software megunolink. Bahasa pemograman yang digunakan adalah bahasa C. Compiler yang digunakan adalah Codevision AVR Compiler.

Pengolahan data dari penelitian ini yaitu untuk mengetahiu ketepatan dan ketelitian dari alat ukur yang dibuat, untuk mengetahui ketepatan dari alat ukur hal pertama yang harus di cari yaitu per. sen kesalahan, rumus dari persen kesalahan dapat dilihat pada persamaan 1:

persen kesalahan $=\frac{\boldsymbol{Y}_{\boldsymbol{n}}-\boldsymbol{X}_{\boldsymbol{n}}}{\boldsymbol{Y}_{\boldsymbol{n}}} \boldsymbol{x} \mathbf{1 0 0} \%$

dimana $: Y n=$ Nilai sebenarnya dan $X n=$ Nilai yang terbaca pada alat ukur.

Ketepatan pengukuran dari suatu sistem pengukuran dapat ditentukan melalui Persamaan :

$A=1-\left|\frac{Y_{n}-x_{n}}{Y_{n}}\right|$

Ketepatan relatif rata-rata dari sistem pengukuran dapat ditentukan melalui Persamaan:

$\% A=1-\left|\frac{Y_{n}-x_{n}}{Y_{n}}\right| x \mathbf{1 0 0} \%$

Hasil pengukuran dinyatakan dalam $X \pm \Delta X$ kemudian dapat ditentukan nilai rata-rata, 
standar deviasi, kesalahan mutlak dan relatif serta pelaporan hasil pengukuran. Nilai rata-rata pengukuran dinyatakan dengan $\bar{X}=\frac{1}{n} \sum_{n=1}^{n} X_{n}$

Xn adalah nilai dari data ke-n dan $n$ adalah jumlah total pengukuran. Ketelitian dapat diekspresikan dalam bentuk matematika sebagai berikut:

Precision $=1-\left|\frac{X_{n}-\bar{X}}{\bar{X}}\right|$

$\mathrm{Xn}$ adalah nilai dari data ke-n dan $\mathrm{n}$ adalah jumlah total pengukuran.Untuk mengukur standar deviasi dapat digunakan Persamaan:

$\Delta X=\frac{1}{n} \sqrt{\frac{n \sum X_{i}^{2}-\left(\sum X_{i}\right)^{2}}{n-1}}$.

(6)

Dari hasil pengukuran dapat dilihat seberapa besar kesalahan relatif pengukuran pada alat dengan menggunakan Persamaan:

$K R=\frac{\Delta X}{\bar{X}} \boldsymbol{x} 100 \%$

\section{HASIL DAN PEMBAHASAN}

Hasil penelitian adalah bagian terpenting dari penelitian ini karena akan dibahas mengenai hasil rancangan dari sistem pengukuran kelajuan angin menggunakan sensor Optocoupler dengan display PC secara terperinci dan data hasil pengukuran yang didapatkan. Melalui pengolahan data yang diperoleh, dapat dilihat hubungan antara variabel-variabel yang diukur.

Untuk mendapatkan kesesuaian data yang tercatat oleh alat ukur maka akan dilakukan analisis data. Analisis data yang dilakukan baik secara pengukuran maupun secara perhitungan memeberikan gambaran kesesuaian antara ketepatan dan ketelitian dari alat ukur ini. Penyajian data ditampilkan dalam tabel dan grafik. Hasil pengolahan data dianalisis dengan tujuan penelitian yang telah ditetapkan.

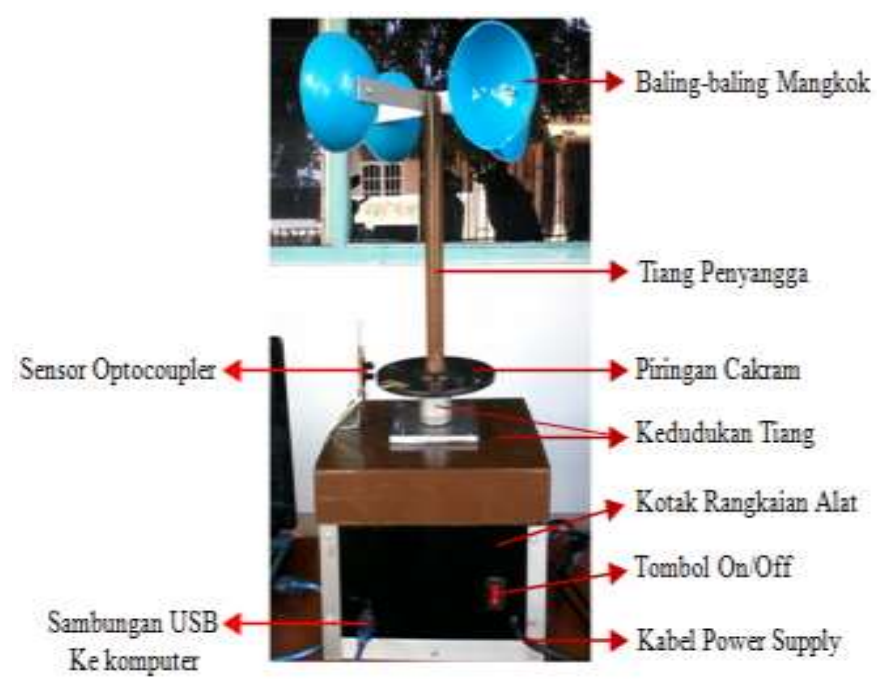

Gambar 7. Foto Hasil Desain Alat Ukur

\section{Spesifikasi performansi Sistem}

Spesifikasi performansi dari sistem alat ukur kelajuan angin ini merupakan pengidentifikasian atau pengurai fungsi setiap bagian pembentuk sistem pengukuran kelajuan angin. Adapun bentuk sistem pengukuran kelajuan angin dapat dilihat pada gambar 7 .

Gambar 7 merupakan hasil desain alat ukur kelajuan angin, secara umum alat ukur ini 
terdiri dari dua bagian.Bagian pertama adalah bagian sistem mekanik alat ukur yang terdiri dari baling-baling dengan tiang penyangga beserta dudukannya yang terbuat dari kayu, kemudian yang kedua yaitu box atau kotak yang berfungsi untuk meletakkan rangkaian elektronika pembangun sistem.
Rangkaian sensor Optocoupler dalam sistem ini diletakkan didepan piringan cakram yang terhubung dengan baling-baling melalui tiang penyangga. Ketika ada angin, balingbaling akan berputar sehingga mengakibatkan piringan cakram juga ikut berputar.

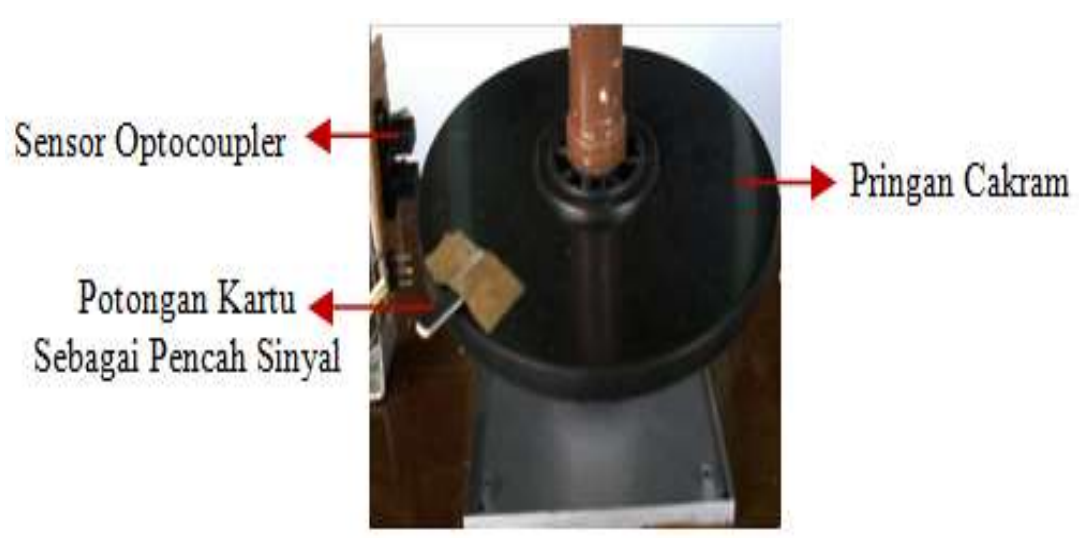

Gambar 8 Piringan Cakram Pencacah Sinyal Sensor

Dari berdasarkan Gambar 8 dapat dilihat, pada piringan cakram ditempelkan potongan kartu kecil yang berfungsi untuk membedakan antara high dan low pada sensor Optocoupler.
Sehingga sensor akan mencacah dan mengirimkan sinyal ke board mikrokontroler Arduino Uno. Berikut merupakan Gambar dari penyusun alat ukur kelajuan Angin.

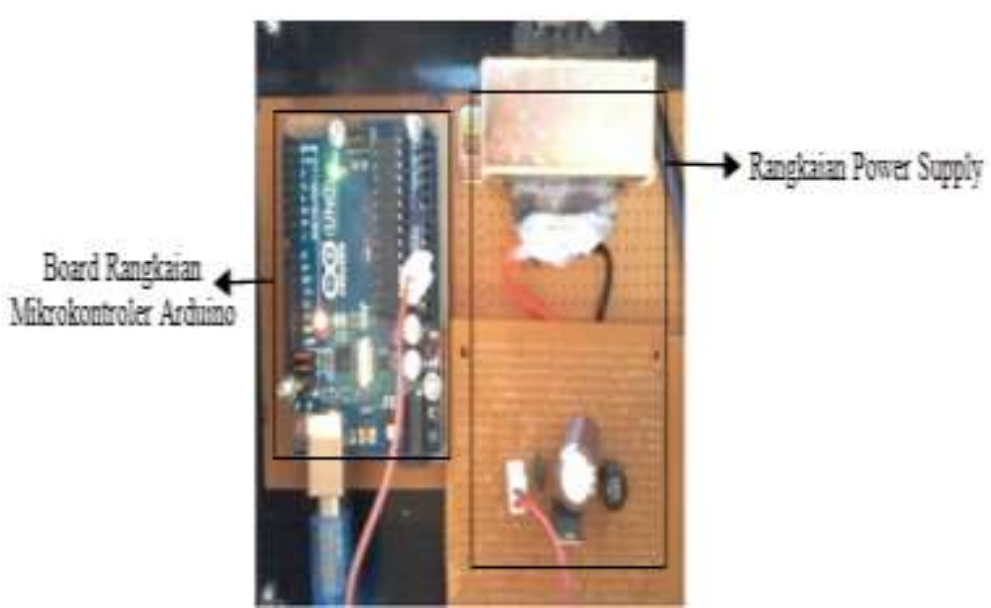

Gambar 9. Cara Pemasangan Sensor Ultrasonik 
Rangkaian dari penyusun dari alat ukur kelajuan angin ini sangat sederhana, hanya terdiri dari rangkaian sensor Optocoupler dengan dua resistor dan board rangkaian arduino beserta rangkaian power supply, sebagai catu daya alat ukur. Keluaran dari sistem alat ukur berupa nilai dan grafik yang ditampilkan pada layar PC.

\section{Spesifikasi desain Sistem}

Penentuan Ketepatan Sistem

Ketepatan pengukuran pada sistem alat ukur ini dilakukan dengan membandingkan hasil pengukuran dari sistem alat ukur dengan alat ukur standar. Proses pengambilan data dilakukan sama seperti sebelumnya, alat ukur kelajuan angin yang dibuat diletakkan sejajar dengan Alat ukur Standar atau Anemometer Lapangan di BMKG. Melalui pengukuran ini didapatkan nilai rata-rata, persentae kesalahan, ketepatan relatif dan persentase kesalahan.

Perhitungan nilai rata-rata, persentase kesalahan, ketepatan relatif dan persentase kesalahan ketepatan untuk pengukuran kelajuan angin dapat dilihat pada Tabel 1 .

Tabel 1. Ketepatan Sistem Pengukuran Kelajuan Angin

\begin{tabular}{|c|c|c|c|c|}
\hline $\begin{array}{c}\text { Wakto } \\
\text { Penglikuran }\end{array}$ & $\begin{array}{c}\text { Pengakuran } \\
\text { AUS }\end{array}$ & $\begin{array}{c}\text { Pengekuran } \\
\text { AUD }\end{array}$ & $\begin{array}{l}\text { Kesalahan } \\
\text { Relatif(\%) }\end{array}$ & $\begin{array}{l}\text { Ketepatan } \\
\text { Relatif (\%) }\end{array}$ \\
\hline $1(10.00 \mathrm{WB})$ & 139 & 1.16 & 16.55 & 0.84 \\
\hline $2(1030 \mathrm{WB})$ & 1.11 & 115 & -3.60 & 097 \\
\hline $3(11.00 \mathrm{WB})$ & 222 & 200 & 991 & 090 \\
\hline $4(1130$ WB $)$ & 222 & 201 & 9.46 & 090 \\
\hline $5(1200 \mathrm{WB})$ & 3.06 & 327 & -6.86 & 0.93 \\
\hline $6(1230 \mathrm{WB})$ & 222 & 201 & 9.46 & 0.90 \\
\hline $7(13.00 \mathrm{WB})$ & 1.11 & 115 & -3.60 & 097 \\
\hline $8(1330 \mathrm{WB})$ & 0.56 & 0.54 & 3.57 & 0.97 \\
\hline $9(1400 \mathrm{WB})$ & 1.11 & 1.14 & -270 & 097 \\
\hline 10 (1430 WB) & 0.56 & 0.56 & 0.00 & 0.99 \\
\hline
\end{tabular}

Pada Tabel 1 dapat dilihat bahwa pengujian dilakukan setiap setengah jam sekali sebanyak 10 kali pengukuran yang dimulai dari pukul 10.00 WIB hingga 14.30 WIB. Untuk data lebih lengkapnya dapat dilihat pada Tabel 6 Lampiran 3. Berdasarkan data kelajuanangin yang diperoleh didapatlah grafik seperti yang terlihat pada Gambar 10. 


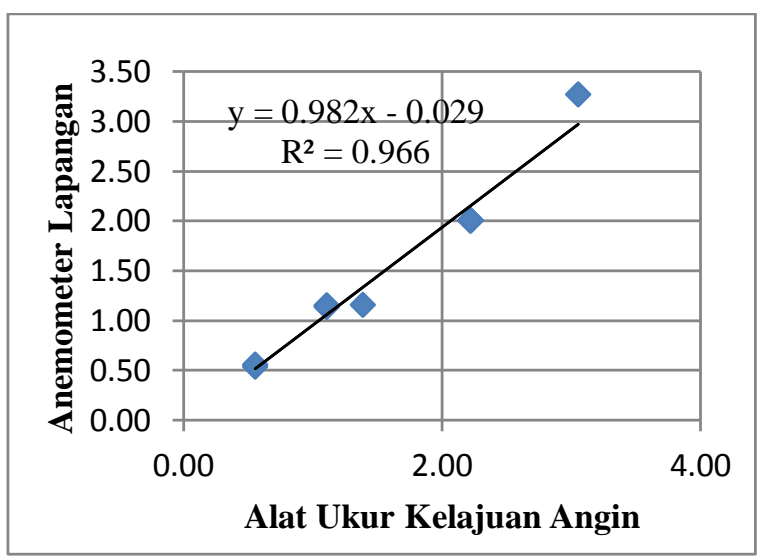

Gambar 10. Grafik Perbandingan Pengukuran Kelajuan Angin menggunakan Alat Ukur dengan Anemometer Lapangan di BMKG

Gambar 10 menunjukkan grafik perbandingan antara kelajuan angin yang terukur dari alat ukur yang dibuat dengan anemometer lapangan di Stasiun Klimatologi Sicincin. Dari grafik didapatkan persamaan linier perbandingan kelajuan angin dari alat ukur dengan alat ukur standar adalah $\mathrm{Y}=$ $0.982 \mathrm{X}$ - 0.029, dimana $\mathrm{Y}$ adalah kelajuan angin dari alat ukur standar dan $\mathrm{X}$ adalah hasil pengukuran kelajuan angin dari alat ukur dengan determinan $R^{2}=0.966$.
Berdasarkan persamaan diatas dapat diambil kesimpulan bahwa, alat ukur kelajuan angin yang dibuat $98 \%$ mendekati kelajuan angin yang diukur menggunakan alat ukur standar dengan determinan $\mathrm{R}^{2}=0.966$ anemometer juga memiliki kaitan yang erat dan sudah dapat dijadikan sebagai alat ukur kelajuan angin. Untuk melihat perbandingan perbedaan pengukuran kelajuan angin menggunakan Anemometer Lapangan terhadap alat ukur yang dibuat untuk yang lebih jelasnya dapat dilihat pada Gambar 11.

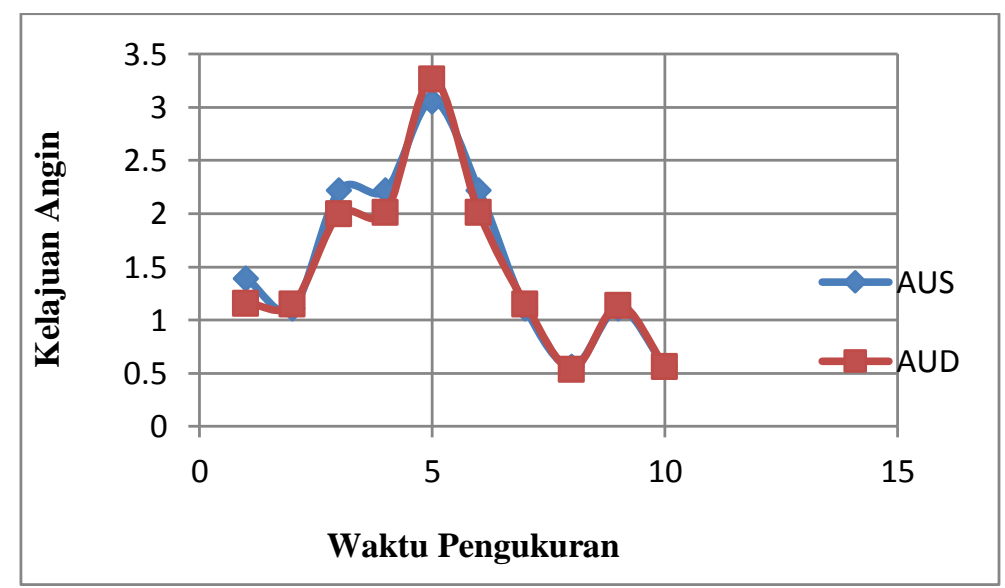

Gambar 11. Grafik Pengukuran Kelajuan Angin menggunakan Anemometer Lapangan terhadap Alat Ukur Kelajuan Angin 
Pada Gambar 11 dapat dilihat hampir semua hasil pengukuran kelajuan angin menggunakan Alat ukur yang dibuat (AUD) mendekati hasil pengukuran Anemometer Lapangan sebagai Alat Ukur Standar (AUS).

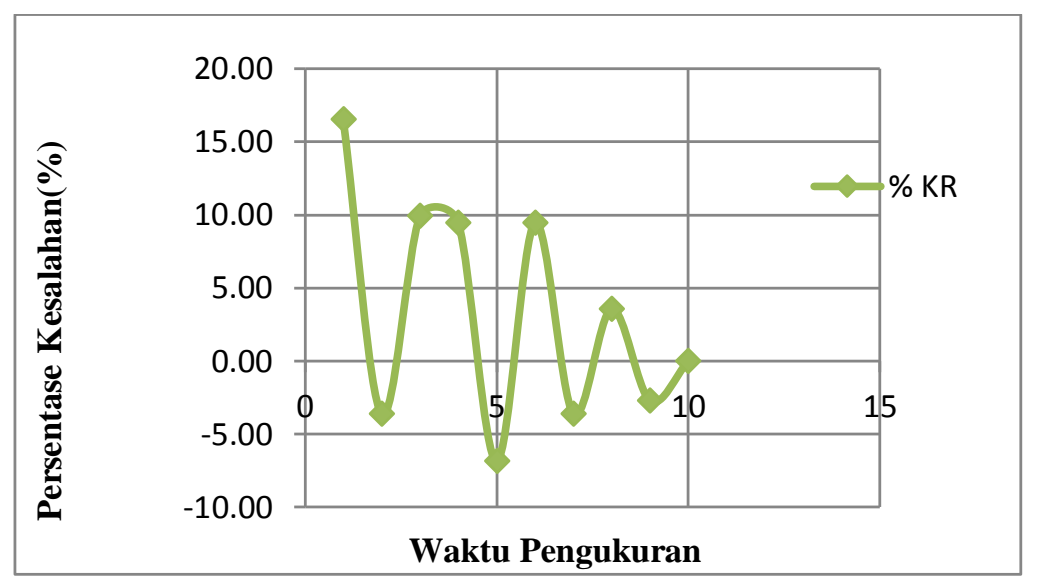

Gambar 12. Grafik Persentase Kesalahan yang terjadi pada saat Pengukuran

Dari hasil pengolahan data yang di masukkan ke grafik pada Gambar 12 persentase kesalahan yang terjadi berkisar antara $-2,70 \%$ sampai dengan $16.55 \%$ dengan persentase

Penentuan Ketelitian Sistem

Untuk menentukan ketelitian dari pengukuran ini, dilakukan pengukuran berulang. Setiap variasi dilakukan pengukuran sebanyak 3 variasi kecepatan kipas angin dengan 6 kali variasi pengukuran berulang.Ini bertujuan untuk memperbanyak data pada proses pengolahannya, selain itu pengukuran yangberulang sangat dianjurkan untuk mencari atau mendekati nilai yang sebenarnya.

Berdasarkan pengukuran dapat ditentukan nilai rata-rata, standar deviasi, kesalahan rata-rata $3.22 \%$. Ketepatan relatif dari alat ukur ini berkisar antara 0.84 sampai 0.99 dengan persentase ketepatan adalah $93.42 \%$.

persentase simpangan dan ketelitian. Data statistik pengukuran berulang untuk alat ukur kelajuan angin dapat dilihat pada Tabel 7 Lampiran 4. Ketelitian pengukuran kelajuan angin dari alat ukur ini diperoleh dengan mengukur kelajuan angin dengan 10 variasi, yaitu dengan memvariasikan kelajuan dan tata letak kipas angin, dimana untuk satu variasi dilakukan pengukuran berulang sebanyak 5 kali pengulangan. Ketelitian pengukuran kelajuan angin dapat dilihat pada Tabel 2 . 
Tabel 2. Ketelitian Pengukuran Kelajuan Angin

\begin{tabular}{|c|c|c|c|c|c|}
\hline Pengling & $\begin{array}{l}\text { Tarats- } \\
\text { Rats }\end{array}$ & P & $\Delta \bar{I}$ & $T a=1 I$ & $\mathbb{R R}(y)$ \\
\hline 1 & 155 & 094 & 002 & $155=002$ & 111 \\
\hline 2 & 157 & IA & 003 & $157=0.003$ & 169 \\
\hline 3 & 185 & 098 & 001 & $185=0.01$ & 030 \\
\hline 4 & 199 & 1.4 & 0.03 & $199=0.03$ & 165 \\
\hline 5 & 232 & 161 & 002 & $232=002$ & 0.70 \\
\hline 6 & 241 & 098 & 0.02 & $2.41=0.02$ & 0.69 \\
\hline 7 & 250 & 100 & 0.03 & $250=0.03$ & 118 \\
\hline 8 & 245 & 094 & 0.03 & $2.55=0.06$ & 119 \\
\hline 9 & 177 & 098 & 0.02 & $177=0.02$ & 111 \\
\hline 10 & 167 & 098 & 0.02 & $167=002$ & 1.16 \\
\hline
\end{tabular}

Dari tabel 2 terlihat bahwa alat ukur memiliki ketelitian yang cukup tinggi untuk pengukuran kelajuan angin. Ketelitian rata-rata untuk 6 variasi pengulangan pengukuran kelajuan angin adalah $98.9 \%$ dengan standar deviasi rata-rata 0.02 dan kesalahan relatif ratarata yaitu $1.11 \%$.

Berdasarkan analisis yang telah dilakukan baik secara grafik maupun statistik memberikan hasil penelitian yang sesuai dengan tujuan penelitian. Adapun hasil penelitian yang diperoleh yaitu spesifikasi performansi sistem alat ukur dan spesifikasi desain sistem alat ukur. Sistem ini terdiri dari dua bagian, yaitu bagian rangkaian elektronik dan bagian mekanik. Bagian rangkaian elektronik meliputi rangkaian penyusun sistem alat ukur kelajuan angin, seperti rangkaian catudaya dan board rangkaian Mikrokontroler Arduino Uno Rev3.Bagian mekanik terdiri dari baling-baling mangkok beserta tiang penyangga beserta kedudukannya, piringan cakram dan rangkaian sensor Optocoupler.

Prinsip kerja dari alat ukur yang dibuat hampir sama dengan Anemometer yang ada di Lapangan BMKG Sicincin ataupun Anemometer yang terdapat pada Laboratorium Fisika. Ketika ada angin, maka baling-baling mangkok akan berputar, karena selain mengarah pada satu arah yang sama, balingbaling mangkok juga terbuat dari bahan plastik yang ringan. Berputarnya baling-baling menyebabkan tiang penyangganya beserta piringan cakram juga ikut berputar, sehingga potongan kartu kecil yang terdapat pada piringan melewati sensor Optocoupler.Sensor kemudian mencacah putaran piringan cakram. Keluaran dari sensor ini adlah berupa bilangan analog yang kemudian di konfersi melalui Mikrokontroler Arduino Uno, sehingga keluarannya dalam satuan RPM (radian putaran menit), yang kemudian dikonfersi lagi dalam satuan $\mathrm{m} / \mathrm{s}$.

Pengujian ketepatan alat ukur dilakukan dengan cara membandingkan langsung alat ukur kelajuan angin yang dibuat dengan alat ukur lapangan yang ada di Stasiun Klimatologi Sicincin (BMKG Sicincin) dan pengujian ketelitian alat ukur dilakukan dengan cara membandingkan alat ukur kelajuan angin yang dibuat dengan alat ukur standar di Laboratorium Elektronika dan Instrumentasi Fisika yang sebelumnya telah dilakukan pengujian terhadap alat ukur kelajuan angin lapangan yang terdapat di Stasiun Klimatologi Sicincin (BMKG Sicincin). Dari hasil pengukuran didapatkan perbedaan yang didapat perbandingannya dengan besar persentase ketepatan rata-rata yang diperoleh dari perbandingan ini adalah 93.99\% dengan persentase kesalahan rata-rata yang didapat yaitu $6.01 \%$. Besar angka ketepatan tersebut diperoleh karena resolusi pada anemometer yang terdapat di Laboratorium Fisika dan Alat Ukur yang dibuat 
adalah $0,01 \mathrm{~m} / \mathrm{s}$, sedangkan resolusi pada anemometer lapangan adalah $0,1 \mathrm{~m} / \mathrm{s}$, sehingga cukup berpengaruh saaat pengolahan data (angka penting) namun perbedaannya tidak begitu jauh, karena itu untuk pengujian alat ukur kelajuan angin yang dibuat dilakukan dengan cara membandingkan alat ukur kelajuan angin yang dibuat dengan Anemometer yang terdapat di Laboratorium Fisika saja, dengan bantuan kipas angin untuk mendapatkan beberapa variasi kecepatan.

Berdasarkan hasil pengujian yang dilakukan, ketepatan relatif dari alat ukur ini berkisar antara 0.84 sampai 0.99 dan persentase ketepatan adalah $93.42 \%$ dengan persentase kesalahan rata-rata $3.22 \%$ dan untuk ketelitian rata-rata kelajuan angin adalah 98.9\% dengan standar deviasi rata-rata 0.02 dan kesalahan relatif rata-rata yaitu $1.11 \%$. Kelajuan angin minimal yang dapat diukur dari alat ukur ini adalah $0.01 \mathrm{~m} / \mathrm{s}$ dengan kelajuan angin maksimalnya yaitu $5.40 \mathrm{~m} / \mathrm{s}$ karena keterbatasannya sumber angin yang tersedia.

Kelebihan dari alat ukur ini adalah memiliki sistem mekanik yang sederhana dan ringan, kemudian tampilan keluaran dari alat ukur ini sudah terkoneksi ke PC, dengan tampilan nilai dan grafik melalui program megunolink yang sederhana dan mudah di jalankan dengan data yang dapat disimpan untuk kemudian diolah. Namun penyimpanan data belum otomatis, sehingga untuk penyimpanan data masih perlu kontrol manual dan tidak memiliki memori eksternal dalam kapasitas yang cukup besar dan data yang diperoleh belum memiliki format waktu yang lengkap. Pada tampilan grafik hanya terdapat waktu tanpa adanya penentuan hari dan tanggal. Selain itu data yang diperoleh dari pengukuran alat ukur kelajuan angin bukanlah data rata-rata kelajuan angin namun hanya data sesaat kelajuan angin. Jadi perlu dilakukan penelitian atau percobaan lebih lanjut untuk penyempurnaanya untuk menghasilkan alat yang lebih tepat, teliti dan dapat dihandalkan.

\section{KESIMPULAN DAN SARAN}

\section{Kesimpulan}

Berdasarkan Berdasakan hasil pengujian dan analisis terhadap besaran fisika yang ada pada alat ukur kelajuan angin menggunakan sensor Optocoupler dengan display PC ini dapat dikemukaakan beberapa kesimpulan dari penelitian yaitu:

1. Hasil spesifikasi performansi dari sistem alat ukur ini terdiri dari dua bagian, yaitu bagian rangkaian elektronik dan bagian mekanik. Bagian rangkaian elektronik meliputi rangkaian penyusun sistem alat ukur kelajuan angin, seperti rangkaian catudaya dan board rangkaian Mikrokontroler Arduino Uno Rev3. Bagian mekanik terdiri dari baling-baling mangkok beserta tiang penyangga beserta kedudukannya, piringan cakram dan rangkaian sensor Optocoupler.

2. Hasil spesifikasi desain alat ukur ini adalah (a) ketepatan dari sistem alat ukur ini cukup baik, untuk pengukuran kelajuan angin bahwa persentase kesalahan rata-rata $3.22 \%$, dengan persentase ketepatan sistem yaitu 93,42\% dan (b) Ketelitian rata-rata dari sistem pengukuran juga cukup baik. Untuk pengukuran kelajuan angin diperoleh ketelitian rata-ratanya adalah $98.9 \%$ dengan standar deviasi rata-rata 0,02 dan kesalahan relatif rata-rata $1.11 \%$.

\section{Saran}

Berdasarkan pembahasan yang telah dipaparkan sebagai saran untuk tindak lanjut dan pengembangan penelitian ini yaitu:

1. Perlu dilakuan penelitian untuk sistem kontrol otomatis untuk mengambil dan membaca atau mendownload data, misalnya dengan sistem menggunakan tombol. Kemudian pengembangan untuk media penyimpanan data yang tidak hanya di PC saja, sebagai data logger dengan kapasitas yang lebih besar misalnya SDcard, sehingga penyimpanan data bisa lebih lama ketika catu daya atau arus PLN mati.

2. Pada pembuatan mekanik alat perlu dilakukan perbaikan lebih lanjut agar sistem alat kokoh dan stabil meskipun untuk kelajuan angin yang akan akan lebih kuat.

3. Alat ukur kelajuan angin menggunakan sensor Optocoupler dengan display PC ini dapat digunakan di Laboratorium Fisika sebagai sarana praktikum dan pada Stasiun BMKG sebagai tambahan referensi pengamatan terhadap kelajuan angin. 


\section{DAFTAR KEPUSTAKAAN}

Bonadin, Rizal. 2005. Alat Petunjuk Arah Angin dan Pengukur Kecepatan Angin Berbasis Mikrokontroller AT89C51. Semarang Univeristas Diponegoro.

Fraden, Jacob. 1996. The Hand Book of Modern Sensor. California: Thermoscan, Inc.

Kadir, Abdul. 2013. Panduan Praktis Mempelajari Mikrokontroler dan Pemrogramannya Menggunakan Arduino. Yogyakarta: Andi.

Kustija, Jaja. 2010. Sistem Instrumen Elektronika Penggunaan Op-amp Untuk Penguat Instrumentasi dan Penguat Log dan Antilog. Modul 8-14 Sistem Instrumentasi. (diakses 04 Des 2014).

Lakitan, Benyamin. 1997. Dasar-dasar Klimtologi. Jakarta: PT. Raja Grafindo Persada

Mega, Umami Riza. 2010. Perancangan dan Pembuatan Alat Pengendali Asap Rokok Berbasis Mikrokontroler AT89S8252. Malang: UIN Maulana Malik Ibrahim

Nopa, Gunawan Putu. 2011. Laporan Praktikum Rangkaian Listrik dan Rangkaian Logika Power Supply. Makasar Universitas Hasanuddin.
Novita Dewi, Annisa.dkk. 2012. Adaptive Neuro-Fuzzy Inference System Untuk Peramalan Kecepatan Angin Di Bandara Juanda Surabaya. Surabaya : ITS

Pesma, Rhahmi Adni dkk. 2013. "Rancang Bangun Alat Ukur Kelajuan dan Arah Angin Berbasis Mikrokontroler Atmega 8535 Menggunkan Sistem Sensor Cahaya. Jurnal Fisika Unand Vol. 2 (4): 238-246.

Safrianti, Ery dkk. 2010. Perancangan Alat Ukur Kecepatan dan Arah Angin. Jurnal Rekayasa Elektrika Vol. 9 (1): 30-35.

Subito, Merry dan Rizal. 2012. Alat Pengukur Energi Listrik Menggunakan Sensor Optocoupler dan Mikrokontroler AT89S52. Jurnal Ilmiah Foristek Vol.2 (2): 184-189.

SuryatRafi'i. 1995. Meteorologi dan Klimatologi. Angkasa: Bandung

SuryatRafi'i. 1995. Meteorologi dan Klimatologi. Angkasa: Bandung 